\title{
Work Organization and Technology: Introduction to the Theme of the Special Issue
}

\author{
I Arja Haapakorpi \\ Researcher, Adjunct Professor, PhD (sociology), University of Helsinki, Finland
}

\section{Tuomo Alasoini}

Chief Adviser, Business Finland

Adjunct Professor, University of Helsinki, Finland

\begin{abstract}
he relationship between work organization and technology has been conceptualized in economic and sociological studies in a variety of ways, depending on the authors' ontological premises and use of terminology (e.g., Leonardi \& Barley, 2010; Mackenzie \& Wajcman, 1985). For one thing, many economic analyses have not even regarded work organization as an analytical entity in itself but rather as a subcategory under an umbrella category of 'technology'. In cases like this, the concept of technology has been used in the broad sense, also referring to human activities and know-how to do things. In many classical and modern sociological studies of work, the analytical distinction between work organization and technology has been of crucial importance, often based on a narrower concept of technology as a set of physical objects.

Yet, those academics that have made a distinction between work organization and technology may have viewed the mutual relationship of these two concepts differently. One such difference concerns the degree of independence of work organization from technology. Although most academics today would probably reject the idea that work organization is a straightforward derivative from the applied technology, contemporary academic discourse - let alone public debate - on the subject is not completely free from the fallacy of technological determinism. This is clearly seen, for example, in the recent discussion on the 'effects of automation' on jobs and employment (e.g., Frey \& Osborne, 2013; 2017; see also Arntz et al., 2016; Atkinson \& Wu, 2017).
\end{abstract}

The idea that the social and technical systems of work should be designed in tandem, instead of regarding work organization as a derivative from technological solutions, is a starting premise of sociotechnical theory. Sociotechnical theory was originally developed in the post WWII England by researchers of the Tavistock Institute of Human Relations in London, based on studies in Yorkshire coal mines (Trist \& Bamforth, 1951). Afterward, sociotechnical theory has evolved into different schools of thought while each of them retaining the core premise of the need for joint optimization of the social and technical systems of work (Van Eijnatten, 1993). The key ideas of sociotechnical theory quickly gained a foothold in Norway, where the consensual climate of industrial relations was conducive to experiments with job redesign and new forms of work organization for the promotion of industrial democracy (Qvale, 2002), and later to other Nordic countries (e.g., Kamp et al., 2014; Karlsson, 1995; Vartiainen, 1994). In recent years, we have witnessed a further spread of these ideas in all the Nordic countries

\footnotetext{
${ }^{1}$ You can find this text and its DOI at https://tidsskrift.dk/njwls/index
} 
under a broad category of social constructivism, having a major influence on working life studies and giving rise to numerous projects and programs for the development of working life.

Another major factor that distinguishes authors in their approaches to the relationship between work organization and technology is how much weight is given to work organization vs. technology as a factor of productivity and performance. Technological progress as such is often regarded as the driver of productivity growth in modern economies. New technological devices and systems - such as robots, smartphones, or autonomous vehicles - are visible, 'sexy', and often released or otherwise promoted with great hype. For example, in a recent report of Accenture, artificial intelligence in the form of robots and intelligent machines is raised to a position of the 'fourth factor of production' alongside labor, capital, and 'ordinary technology' (Purdy \& Daugherty, 2016). In a similar vein, Klaus Schwab (2016) talks about the 'fourth industrial revolution', based on a huge development of technologies and leading to profound, irresistible changes in all aspects of life.

Many social scientists have shown a much more cautious, if not critical, attitude toward the superiority of technology as a driving force. One of them is Elias Sanidas (2005) who largely questions the view of organizational innovations taking second place to technical innovations in explaining industrial growth in the USA and Japan in his time-series analysis of factors of growth in these two countries. In his view, the role of changes in work organization in explaining industrial and economic growth should be more generally seen as significant as changes in the quantity and quality of capital and labor. Drawing on a Dutch study, Frank Pot (2011) argues that the role of nontechnological or social innovation in radical innovation is even more important than that of technological innovation. According to the study he refers to, social innovation accounts for as much as $75 \%$ of success in radical innovation, whereas in incremental innovation, the role of social and technological innovation is equally important. In their recent article, Jürgen Howaldt, Ralf Kopp, and Jürgen Schultze (2017) criticize the visions of the German Industry 4.0 strategy as being based on a one-sided, technology-oriented understanding of innovation. They regard the notion of Industry 4.0 as reminiscent of the old disappointed hopes of fully automated factories. At the same time, they argue that it is highly unlikely that even quantum leaps in technological development would seriously undermine the role of the complex interplay between social and technological innovations as a precondition for the success of the new strategy.

The conceptual separation of work organization and technology, either as discrete and independent entities or mutually dependent systems, is taken for granted in most studies on working life. However, a growing body of research literature, which Orlikowski and Scott (2008) position under the banner of 'sociomateriality', questions the rationale of such separation. According to the relational ontology that is characteristic of sociomaterial analyses (e.g., actor-network theory), the social and the material are inherently inseparable even to the degree that neither the social (work organization) nor the material (technology) has inherent properties without their interpenetration. Sociomaterial ontology leads to a radically new kind of terminology and research agenda concerning, for example, the ongoing digitalization of products, services, and operational processes by rejecting the idea of separation between social (or organizational) and technological innovation in favor of concepts such as new 'sociodigitized structures'.

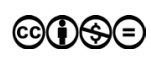




\section{Contributions}

This special issue is based on papers that were submitted to a call entitled 'Work Organization and Technology - Strategy, Negotiation and Application' in May 2017. The aim of the special issue is to discuss theoretical approaches, to present results and conclusions of empirical studies, and to promote research on the relationship and interaction between work organization and technology. The issue comprises four articles, which examine the complex relationship between the two key concepts of the call - work organization and technology - from different perspectives.

Katia Dupret and Bjarke Friborg contribute in their article 'Workarounds in the Danish Health Sector - from Tacit to Explicit Innovation' to a better understanding of the implementation of new technologies in the Danish health care sector and the social context in which these technologies are utilized. Their theoretical approach is based on actor-network theory and science and technology studies and their methodological approach on ethnographic. Their research problem stems from the application of new management paradigms such as New Public Management in the work of health care professionals. New Public Management promotes productivity, effectiveness, and measurability. As regards the implementation of technology, the dominating managerial strategy focuses on standardization of the work organization, practices, and relations and mainstreaming 'best practices', while disregarding the case-specific nature of the problems or challenges that health care professionals have to solve in their daily work. Meeting this contradiction leads to 'invisible work', that is, tasks that are not counted as formal work by the management system. Technology workarounds - the main object of the study - are small-scale informal innovations with which the health care professionals tackle challenging situations by making innovative use of new technologies.

The Nordic perspective comes out in an implicit way in the article. The Nordic countries are often regarded in research literature as havens of democratic and participatory management, but, according to the authors, the Danish regime of industrial relations in the health care sector does not differ so much from that of other European countries with regard to its tradition of top-down management and transnational trend toward standardized work processes. However, and despite the above, health care professionals still have freedom to develop bottom-up work practices concerning ways of utilizing technology, albeit these ways are not counted as formal work practices. With standardization, technology-related invisible work is becoming more common. From the viewpoint of planning resource needs and assessing the performance of employees, the large amount of invisible work is problematic. By contributing to a better theoretical understanding of the nature of invisible work, this paper at the same time makes an important contribution to the discussion about the design and organization of work of health care professionals in high-tech work environments.

Laura Bordi, Jussi Okkonen, Jaana-Piia Mäkiniemi, and Kirsi Heikkilä-Tammi contribute in their article 'Communication in the Digital Work Environment: Implications for Wellbeing at Work' to a better understanding of the effects of digital IC technologies on communication in work practices. With the introduction of a growing number of new technologies, the possibilities for communication at work have greatly increased. The increased technology-mediatedness of communication has both positive and negative effects on work processes, interaction, and wellbeing. The authors focus on the effects on the wellbeing at work, approaching them from the perspective of increased 
technology-mediated communication. They find six themes that affect the wellbeing at work in technology-intensive work environments: the volume of digital communication, expectations of constant connectivity, quality of messages, adaptation of new communication tools, technical problems, and flexibility in communication. The cons are related to the multiplicity of technologies and constant connectivity, the poor quality of messages, and insufficient learning opportunities for employees. However, the authors regard the flexibility of mobile technologies as a positive factor for the wellbeing at work. The research was conducted in three organizations: an industrial company, an insurance company, and a financial administration services company.

The subject and the theme of the study is not Nordic in any particular way; the effects of digital technologies on work are a much-discussed topic in all developed countries with a high intensity of advanced IC technologies and work practices in which communication is largely transmitted through these technologies. However, the theme of work-related wellbeing is a Nordic particularity and, in this sense, can be seen as a reflection of the 'Nordic working life model'. Investigating working life through the lenses of wellbeing is a characteristic feature in Nordic working life research, and it has been an object of numerous development programs and projects in these countries. The article continues this tradition, although the authors do not explicitly make that connection.

Jesper Simonsen, Morten Hertzum, and John Damm Scheuer demonstrate in their article 'Quality Development in Health Care: Participation vs. Accreditation' how accreditation in health care should be supplemented with participatory approaches that permit local experimentation. The authors describe and compare two models with each other: the accreditation-based Danish quality model (DQM) and effects-driven information technology development (EDIT). The DQM follows the logic of systematic process focused quality development according to the well-known PDCA (plan-do-check-act) cycle model of Deming. The DQM was introduced to Danish hospitals and other health care units in 2005, but 10 years later, the model was abolished by a decision of the Ministry of Health as being too bureaucratic and time-consuming. EDIT is a sociotechnical instrument for managing ICT projects, deeply rooted in the Nordic tradition of participatory design. It is in the interest of the authors to show how EDIT could be used as a supplementary method to meet the visions of a new quality-development program that is yet to be developed and implemented in Denmark.

The article focuses exclusively on Danish experiences. Denmark is the only Nordic country in which accreditation has been the national strategy for quality development in health care. However, discussion on EDIT brings this article into a broader Nordic perspective. Participatory design is based on principles, such as engagement, learning, motivation, and empowerment of the employees, typically regarded as important in Nordic working life studies and as elementary elements of the 'Nordic working life model'. The authors hope that a participatory design approach like EDIT could inspire designers of quality-development programs and strategies also in the other Nordic countries and in sectors other than health care.

Maral Babapour, MariAnne Karlsson, and Anna-Lisa Osvalder contribute in their article 'Appropriation of an Activity-Based Flexible Office in Daily Work' to discussion on new generation of workplace innovations that are enabled by advanced IC technologies. Their study focuses specially on activity-based flexible offices (A-FOs), that is, open-plan offices in which individuals and teams rotate on a daily basis and have

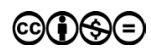


no dedicated places in contrast with traditional cellular office layouts. Using versatile qualitative research information, the authors try to show the different ways in which employees in a case organization appropriated desk sharing and speech policies in an A-FO and to find reasons for such differences. The case organization is a small Science Park in Sweden. Three groups of employees with different strategies are distinguished: mobile workers who were ready to adopt the desk-sharing policy, dwellers who rejected the new policy, and experimenters who shifted between adoption and rejection. A key conceptual starting point for the authors in their empirical analysis is Rogers' classical textbook on the diffusion of innovations and his grouping of the main attributes of innovation against which the empirical results are mirrored.

The study by Babapour, Karlsson, and Osvalder produces new research information for designers and change process managers who are considering a shift from traditional office layouts to coworking spaces like A-FOs. The authors argue that the participatory tradition included in Nordic working life studies should be followed also when introducing workplace innovations of the digital age. This tradition comprises, above all, employee participation and involvement in systematic work environment management. In the case of the Science Park, the employees were not involved in the design and planning process. The authors suggest that Rogers' main attributes of innovation - relative advantage, compatibility, complexity, observability, and trialability could be utilized when discussing to what extent the new A-FO solutions match the needs of employees.

All four articles deal with the introduction of new technologies and related tensions in situations where new international management paradigms and ideologies encounter time-honored work practices in Nordic workplaces. On the basis of the articles, it is not possible to identify a special mode of Nordic leadership and management; the described patterns of (re)organizing work and labor are typical for all developed industrial countries. However, clear references to the special Nordic way of thinking and acting emerge in all articles, as certain culturally and socially institutionalized patterns and practices are taken for granted, such as the importance of wellbeing at work in the digital work environment or the need for a participatory design in quality development. Thus, the 'Nordic working life model' - a widely debated theme in multiple issues of NJWLS (e.g., Kasvio et al., 2012) - is still thriving in the ongoing technological transition both as workplace practices and as the subject and inspiration of Nordic working life studies.

\section{References}

Arntz, M., Gregory, T., \& Zierahn, U. (2016). The Risk of Automation for Jobs in OECD Countries: A Comparative Analysis. OECD Social, Employment and Migration Working Papers, No. 189. Paris: OECD Publishing. doi: http://dx.doi.org/10.1787/5jlz9h56dvq7-en.

Atkinson, R. D., \& Wu, J. (2017). False Alarmism: Technological Disruption and the U.S. Labor Market, 1850-2015. Information Technology \& Innovation Foundation. http:// www2.itif.org/2017-false-alarmism-technological-disruption.pdf.

Frey, C. B., \& Osborne, M. A. (2013). The Future of Employment: How Susceptible Are Jobs to Computerisation? OMS Working Papers. University of Oxford. http://www.futuretech.ox.ac.uk/sites/futuretech.ox.ac.uk/files/The Future of Employment OMS Working Paper 0.pdf. 
Frey, C. B., \& Osborne, M. A. (2017). The future of employment: how susceptible are jobs to computerisation?, Technological Forecasting and Social Change, 114(C): 254-280. doi: https://doi.org/10.1016/j.techfore.2016.08.019.

Howaldt, J., Kapp, R., \& Schultze, J. (2017). Why Industrie 4.0 needs workplace innovation - a critical essay about the German debate on advanced manufacturing. In P. R. A. Oeij, D. Rus, \& F. D. Pot (Eds.), Workplace Innovation: Theory, Research and Practice (pp. 45-60). Heidelberg: Springer.

Kamp, A., Hasle, P., \& Andersen, P. T. (2014). Revitalisering af socioteknikken - social capital, samarbejdet og sociale relationer [Revitalization of sociotechnics - social capital, cooperation and social relations], Tidsskrift for arbejdsliv, 16(4): 5-10.

Karlsson, U. (1995). The Swedish sociotechnical approach: strengths and weaknesses. In J. Benders, J. de Haan, \& D. Bennett (Eds.), The Symbiosis of Work and Technology (pp. 47-58). London: Taylor \& Francis.

Kasvio, A., Gonäs, L., \& Skorstad, E. J. (2012). In search of the Nordic Working Life Model; introduction to the thematic Issue, Nordic Journal of Working Life Studies, 2(4): 1-19. doi: http://dx.doi.org/10.19154/njwls.v2i4.2302.

Leonardi, P. M., \& Barley, S. R. (2010). What's under construction here? Social action, materiality, and power in constructivist studies of technology and organizing, Academy of Management Annals, 4(1): 1-51. doi: https://doi.org/10.1080/19416521003654160.

Mackenzie, D., \& Wajcman, J. (Eds.) (1985). The Social Shaping of Technology. Milton Keynes: Open University Press.

Orlikowski, W. J., \& Scott, S. V. (2008). Sociomateriality: challenging the separation of technology, work and organization, Academy of Management Annals, 2(1): 433-474. doi: https://doi.org/10.1080/19416520802211644.

Pot, F. (2011). Workplace innovation for better jobs and performance, International Journal of Productivity and Performance Management, 60(4): 404-415. doi: https://doi. org/10.1108/17410401111123562.

Purdy, M., \& Daugherty, P. (2016). Why Artificial Intelligence Is the Future of Growth. Accenture. https://www.accenture.com/lv-en/ acnmedia/PDF-33/Accenture-Why-AI-isthe-Future-of-Growth.pdf.

Qvale, T. U. (2002). A case of slow learning? Recent trends in social partnership in Norway with particular emphasis on workplace democracy, Concepts and Transformation, 7(1): 31-55. doi: http://dx.doi.org/10.1075/cat.7.1.04qva.

Sanidas, E. (2005). Organizational Innovations and Economic Growth: Organosis and Growth of Firms, Sectors and Countries. Cheltenham: Edward Elgar.

Schwab, K. (2016). The Fourth Industrial Revolution. Geneva: World Economic Forum.

Trist, E. L., \& Bamforth, K. W. (1951). Some social and psychological consequences of the longwall method of coal-getting: an examination of the psychological situation and defences of a work group in relation to the social structure and technological content of the work system, Human Relations, 4(1): 3-38.

Van Eijnatten, F. M. (1993). The Paradigm That Changed the Work Place. Assen: Van Gorcum.

Vartiainen, M. (1994). Työn muutoksen työvälineet - muutoksen hallinnan sosiotekniset menetelmät [Tools for changing work - sociotechnical methods for the management of change]. Otaniemi: Otatieto. 